\title{
Burns in the Elderly: Potential Role of Stem Cells
}

\author{
Margarita Elloso ${ }^{1,2,3, *}$, Ankita Kambli ${ }^{1}$, Ayesha Aijaz ${ }^{1,4}$, Alex van de Kamp ${ }^{1}$ \\ and Mark G. Jeschke $1,2,3,5$ (i) \\ 1 Sunnybrook Research Institute, Sunnybrook Health Sciences Centre, Toronto, ON M4N3M5, Canada; \\ ankita.kambli@sri.utoronto.ca (A.K.); ayesha.aijaz@sri.utoronto.ca (A.A.); \\ alex.vandekamp@sri.utoronto.ca (A.v.d.K.); marc.jeschke@sunnybrook.ca (M.G.J.) \\ 2 Department of Laboratory Medicine and Pathobiology, University of Toronto, Toronto, ON M5S1A8, Canada \\ 3 Ross Tilley Burn Centre, Sunnybrook Health Sciences Centre, Toronto, ON M4N3M5, Canada \\ 4 Institute of Medical Science, University of Toronto, Toronto, ON M5S1A8, Canada \\ 5 Division of Plastic and Reconstructive Surgery, Department of Surgery, Faculty of Medicine, \\ University of Toronto, Toronto, ON M5T1P5, Canada \\ * Correspondence: margarita.elloso@mail.utoronto.ca
}

Received: 3 June 2020; Accepted: 22 June 2020; Published: 29 June 2020

check for updates

\begin{abstract}
Burns in the elderly continue to be a challenge despite advances in burn wound care management. Elderly burn patients continue to have poor outcomes compared to the younger population. This is secondary to changes in the quality of the aged skin, leading to impaired wound healing, aggravated immunologic and inflammatory responses, and age-related comorbidities. Considering the fast-growing elderly population, it is imperative to understand the anatomic, physiologic, and molecular changes of the aging skin and the mechanisms involved in their wound healing process to prevent complications associated with burn wounds. Various studies have shown that stem cell-based therapies improve the rate and quality of wound healing and skin regeneration; however, the focus is on the younger population. In this paper, we start with an anatomical, physiological and molecular dissection of the elderly skin to understand why wound healing is delayed. We then review the potential use of stem cells in elderly burn wounds, as well as the mechanisms by which mesenchymal stem cell (MSCs)-based therapies may impact burn wound healing in the elderly. MSCs improve burn wound healing by stimulating and augmenting growth factor secretion and cell proliferation, and by modulating the impaired elderly immune response. MSCs can be used to expedite healing in superficial partial thickness burns and donor site wounds, improve graft take and prevent graft breakdown.
\end{abstract}

Keywords: elderly; mesenchymal stem cells (MSCs); stem cells; wound healing; burn

\section{Introduction}

In 2010, burn injuries cost the Canadian healthcare system \$366 million, making it the top 10 in overall spending [1]. While in the U.S., the average cost of burn management for patients is $\$ 98,000$ for survivors and $\$ 310,000$ for non-survivors [2].

Burn injuries are extremely distressing, leading to lengthy rehabilitation, permanent disabilities and morbidities that affect the individual's activities of daily living [3,4]. Wounds from burn injuries are very different from other traumatic wounds, such as lacerations, avulsions, bite wounds, because heat disrupts the body's homeostasis. Problems arising from burn injuries can be attributed to an increase in the inflammatory and metabolic response, leading to organ dysfunction and systemic failure; burn wound infection from an impaired skin barrier, providing a favorable environment for bacterial proliferation; and a depressed systemic and humoral immune response, putting the patient 
at risk of sepsis [5]. Scarring is also inevitable which leaves patients with functional and aesthetic deformities [6].

The severity (depth and size) of the burn in combination with the patient's age, determines the outcome, risk of complications and survival [7]. Managing elderly burn patients is challenging due to poor wound healing, decreased immunologic responses, comorbidities related to aging, diminished sensation and reduced mobility [8,9]. These factors pose significant challenges to the healthcare system, since the number of elderly burn patients continues to rise as the population continues to age [10]. There were 221,519 burns seen in North America between 2009 and 2018, 17\% of which were aged 60 years and older. This is alarming since the percentage of elderly burns has increased from $12 \%$ to $17 \%$ and it is expected to rise [11].

There have been numerous advances in burn wound management, such as laser doppler imaging of burn wounds which improves burn depth assessment in the early period of burn injury, bioengineered dressings which assist in dermal regeneration and the use of stem cells for wound healing. However, most of these studies focus on the younger population which may be due to the higher number of burn injuries in these populations.

Mesenchymal stem cells (MSCs) have been gaining momentum in the field of regenerative medicine and wound healing since $2000[12,13]$. MSCs have been documented to facilitate cell migration, granulation tissue formation, re-epithelialization, angiogenesis and neovascularization, which enhances wound healing [14]. There are currently six ongoing clinical trials on the use of mesenchymal stem cells in burn wounds, all of which are on younger adults [15-20].

In this paper, we first describe the anatomical composition and cellular biology of the elderly skin that contribute to impaired burn wound healing. We then discuss mechanisms by which MSC-based therapies may impact burn wound healing in the elderly.

\section{Elderly Skin}

The skin is the largest organ of the body with important physiological functions and acts as a protective barrier. It has an essential role in regulating body temperature, conducting sensory impulses, fat and metabolic products [21]. It also maintains water, electrolyte homeostasis and performs various immunologic functions. It protects the body against U.V. radiation, environmental hazards and infection [22].

The skin's integrity and functions change as a person ages which leads to compromised healing [23]. The change in the quality of elderly skin occurs as a result of exogenous and endogenous factors [22]. Exogenous changes occur as a result of lifelong environmental exposures, e.g., smoking leading to cumulative DNA damage; U.V. exposure causing daily multiple cellular DNA changes [24]. Endogenous changes are mostly secondary to genetics which is partly responsible for the chronological physiological aging $[25,26]$. Other factors can be secondary to comorbidities, such as diabetes and vascular diseases which are commonly seen in the elderly population and play a role in delayed healing.

Elderly patients have different skin anatomical compositions and cellular biology compared to the younger population which leads to an intricate interplay of factors, leading to poor wound healing.

\subsection{Anatomical Composition of the Elderly Skin}

The epidermis of elderly skin has a reduced keratinocyte turnover rate, higher $\mathrm{pH}$ and decreased water content in the stratum corneum [22,26-28]. The higher $\mathrm{pH}$ results in a decrease in lipid concentration, leading to defects in the permeability barrier and integrity of the epidermis. These changes in the elderly are visible in the coarseness and irregular pigments of the skin $[29,30]$. The dermo-epidermal junction rete ridges and dermal papillae are flattened. The surface area for communication between the layers is significantly reduced, leading to a decrease in the flow of nutrients and oxygen [21,31]. Changes in the epidermis make the skin atrophied, wrinkled and less resistant to shearing forces, thus more vulnerable to injury [32]. Shear force is generated by the motion of the subcutaneous tissue and bone relative to an immobilized skin [33]. 
The dermis of elderly skin has decreased numbers of fibroblasts, mast cells, melanocytes, Langerhans cells, dendritic cells and dermal appendages [34-36]. There is also an increased degradation of elastin [37]. Collagen quality is reduced, degradation is increased and a disordered collagen network is increased [38]. These changes lead to the thinning out of the extracellular matrix (ECM). Moreover, dermal vascularity is diminished, resulting in reduced blood flow, impaired nutrient exchange and impaired thermoregulation $[39,40]$. These changes render the skin less firm, less elastic and more fragile [41] (Figure 1).

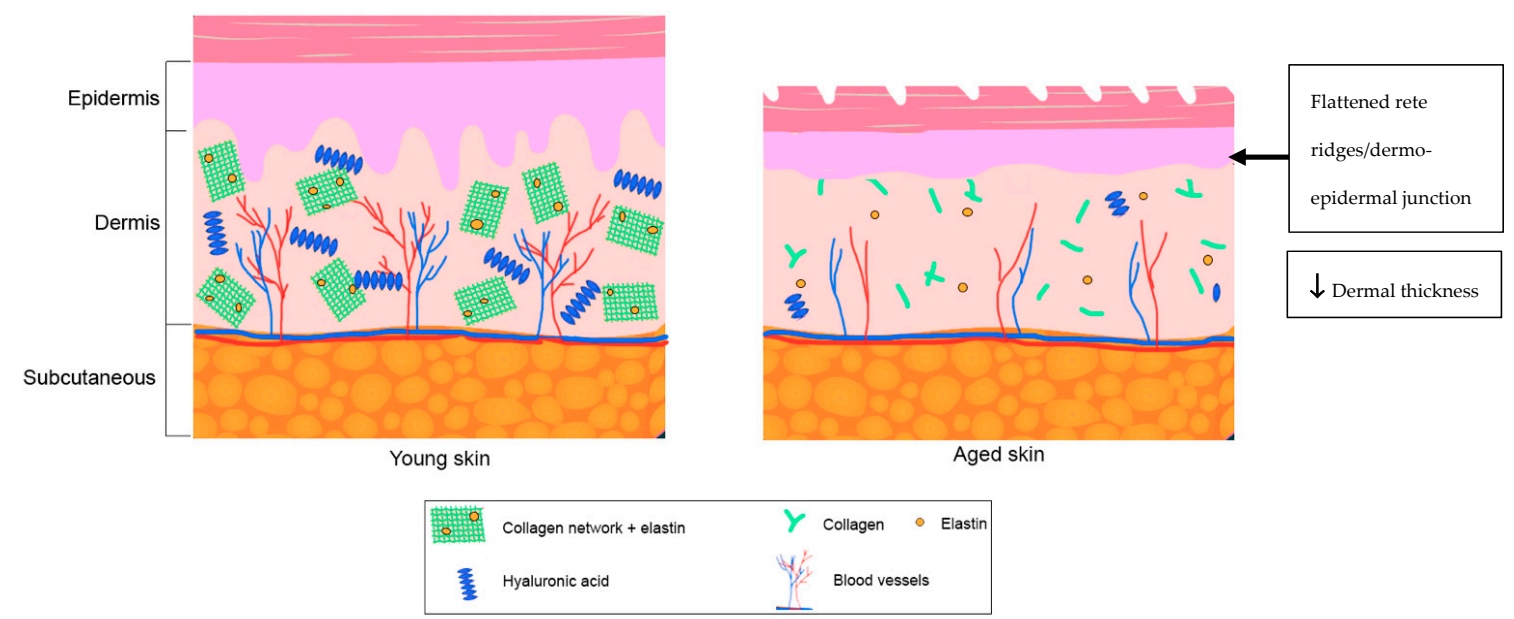

Figure 1. Differences in skin structure between young and aged skin. Collagen and elastin in the aged skin has a reduced quality and a disorganized network. Hyaluronic acid is decreased and vascularization is decreased.

\subsection{Cell Biology of Elderly Skin}

On a cellular level, the elderly skin is different as compared to the younger skin which increases the risk of delayed healing and other complications in burn injuries [42]. As the cell ages, gradual decline, translational defects and oxidative stress increase the amount of cellular destruction, while the ability to repair and control DNA damage decreases.

\subsubsection{Oxidative Stress}

Cells and tissues are generally exposed to low, non-toxic levels of free radicals, such as reactive oxygen species (ROS) and reactive nitrogen species (RNS) [43-45]. ROS are produced in the mitochondria as side products in the electron transport chain of glycolysis $[38,46]$. There is a delicate balance between oxidative stress and antioxidant production $[43,47]$. This balance means that cells can protect themselves from the harmful effects of free radicals in the normal physiologic condition by several antioxidants and their repair enzymes [48]. This balance is disrupted with aging [49,50]. Cell metabolism is disrupted, leading to mitochondrial breakdown. The defective mitochondria produce excess ROS, causing DNA damage [51,52]. High ROS levels also activate stress signaling pathways such as p38 and Forkhead box protein (FOXO), decreasing the cell's ability to protect itself from oxidative stress [53]. Oxidative stress with DNA damage and lipid peroxidation increases cell senescence and apoptosis which is deleterious in wound healing, leading to chronic wounds.

\subsubsection{Telomere Shortening}

ROS and RNS induce changes in skin proteins, resulting in progressive telomere shortening [54-58]. Telomeres are repeating DNA sequences located at the ends of the chromosomes. They cover and protect chromosomal ends from degradation and anomalous recombination [38,59]. They become shorter with each cell division and with aging, ultimately resulting in cellular senescence or further cell death, causing inadequate wound healing $[60,61]$. 


\subsubsection{Cellular Senescence}

Oxidative stress, telomere shortening and DNA damage result in cellular senescence which is the loss of the proliferative capacity or a state of permanent growth arrest [62]. Aging stem cells are affected by senescence through senescence-associated secretory phenotype (SASP) which releases pro-inflammatory signals, thereby disrupting the skin stem cell environment and influencing other cells around the area to deteriorate $[62,63]$. This contributes to the decline of the regenerative potential of skin tissues [64].

In younger individuals, senescent cells accumulate transiently during the proliferative phase of wound healing to facilitate myofibroblast migration and differentiation [65]. Aged and defective cells, however, accumulate and persist in the elderly, secondary to a failing immune response. The persistent accumulation of senescent cells prolongs the phases of wound healing and delays re-epithelialization [66] (Figure 2).

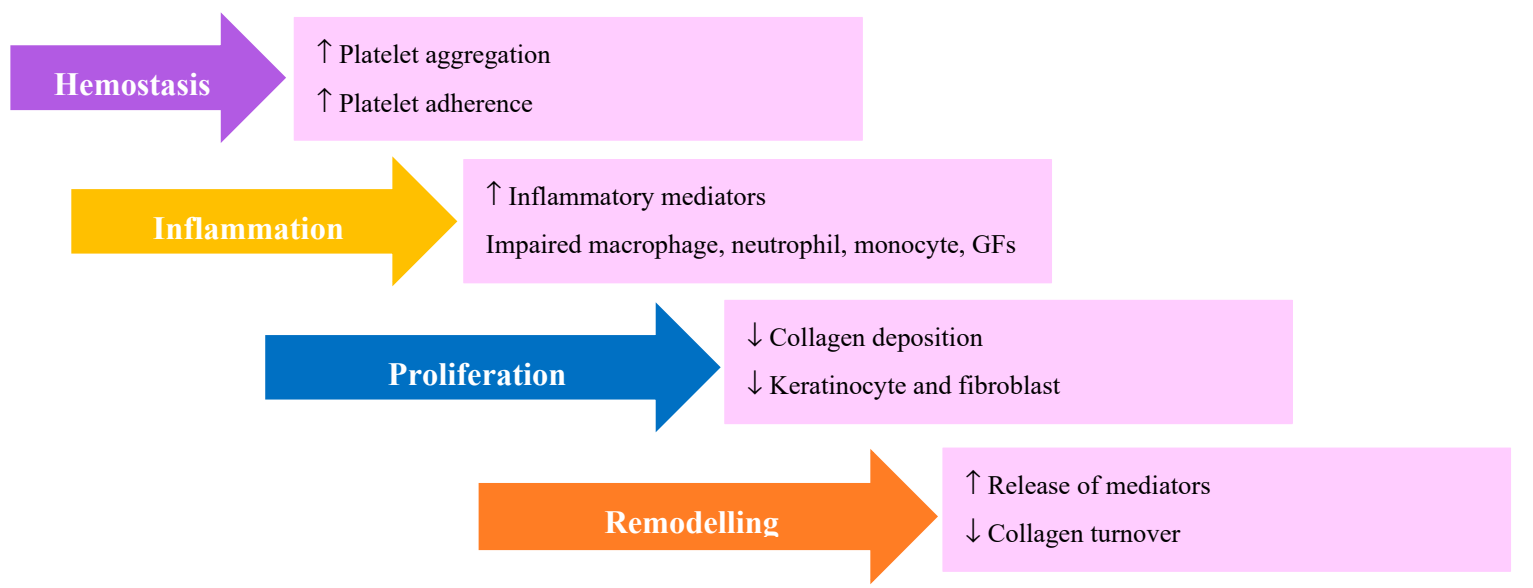

Figure 2. Phases of wound healing with age-related changes. Hemostasis - there is increase in platelet aggregation and adherence. Inflammation -there is increase in inflammatory mediators along with impaired macrophage, neutrophil, monocyte and GFs. Proliferation - there is decrease in keratinocyte, fibroblast and collagen deposition. Remodelling - there is increase in release of inflammatory mediators and decrease collagen turnover. Inflammatory mediators are interleukin (IL)- $1 \beta$, interferon- $\gamma$ (IFN- $\gamma$ ), IL-1 receptor antagonist (RA), IL-6, granulocyte macrophage colony-stimulating factor (GM-CSF), and FMS-like tyrosine kinase 3 ligand (FLT-3L). Growth factors are platelet derived growth factor (PDGF), transforming growth factor (TGF), fibroblast growth factor (FGF), epidermal growth factor (EGF) vascular endothelial growth factor (VEGF), keratinocyte growth factor (KGF).

\subsubsection{Immunosenescence}

Immunosenescence, the deterioration in cell-mediated immune functions, is associated with aging. Immunosenescence affects various cell types (macrophage, neutrophils, monocytes, fibroblasts, Langerhans cells, T-cells, B-cells, natural killer cells, dendritic cells), as well as reduces the humoral immune responses $[42,67,68]$. Elderly individuals have a marked increase in the systemic levels of pro-inflammatory cytokines in the absence of insult resulting in a chronic inflammatory state $[69,70]$. The chronic inflammatory state, combined with increased oxidative stress, creates a vicious cycle which ultimately leads to an increased risk of age-related complications and death [68,71,72].

When exogenous or endogenous factors such as burn afflict an elderly person, the commencing stress response releases more free radicals, initiating lipid peroxidation and high oxidative stress [50,73-76]. Furthermore, age-related damage to the endothelial cells, prolonged recruitment of leukocytes to the wound and delayed keratinocyte migration and epithelialization confound wound healing [77]. Together, these factors lead to cell death and additional insults on defective elderly skin stem cells, enhancing ischemic tissue necrosis [43,78-81]. 
All in all, atrophied, fragile skin, decreased cell repair, inadequate immune response, immunosenescence and pre-existing medical conditions, amongst other problems with aging, predisposes elderly burn patients to delayed healing, higher risk of infection, higher morbidity and mortality $[82,83]$.

The regenerative potential of stem cells might hold the key to address the problem of wound healing in elderly burn patients which is discussed further.

\section{Stem Cells}

\subsection{Stem Cell Classification}

Stem cells are cells that hold the potential to differentiate into many cell types which is contingent on how specialized or potent they already are [84,85]. Following this, stem cells can be classified based on their range of differentiation potential. Totipotent stem cells can differentiate into all types of cells. These can form embryonic and extra-embryonic structures such as the placenta [85]. Pluripotent stem cells, such as embryonic stem cells, can form somatic and germ line cells [86]. Multipotent stem cells can differentiate into specific cell types, in particular tissues or organs; these include hematopoietic stem cells (HSCs), endothelial progenitor cells (EPCs), and mesenchymal stem cells (MSCs) [87]. Stem cells have been used vastly in regenerative medicine due to their unique ability to differentiate into different cell types [88]. However, various ethical issues surround totipotent and pluripotent stem cells, as a result of which MSCs have become popular for research use.

\subsection{MSC Applications in Regenerative Medicine and Wound Healing}

Multipotent MSCs are adult stem cells that can differentiate into mesodermal lineages, including osteocytes, adipocytes, and chondrocytes, as well as neurocytes and hepatocytes, which are of ectodermal and endodermal lineages, respectively [89]. They are defined by the expression of CD105, CD90, CD73 markers, while they lack CD34, CD45, CD11b, CD19, and HLA-DR [90]. The isolation of MSCs has been described from bone marrow, adipose tissue, placenta, amniotic fluid, umbilical cord and skin [89]. Viable MSCs have also been isolated from debrided burned skin that is typically discarded during surgical excision [91]. The availability and differentiation capacity of MSCs have made them excellent candidates for clinical applications.

MSCs have been studied in the context of bone and cartilage reconstruction and nervous system rebuilding, as well as cardiac and liver regeneration [92]. In conjunction with this, research has extended into their applications for wound healing. MSCs promote angiogenesis, re-epithelialization and wound healing, as well as facilitating the reduction of inflammation, making them useful candidates in clinical applications to burn wounds [93]. As a result, these could prove useful in counteracting the negative effects of inadequate healing potential, low collagen quality and diminished dermal vascular density in elderly burns.

\section{Stem Cells and Wound Repair}

Stem cells can facilitate wound healing and closure in burn wounds by promoting ECM reformation, neovascularization, and keratinization [94]. As seen in Figure 3, MSCs can differentiate into various cell types at the site of a wound, as well as recruit fibroblasts, keratinocytes, macrophages and progenitor cells [95]. In addition to this, they also facilitate angiogenesis and neovascularization, as well as influence the growth factor and cytokine profile to promote wound healing [94,95]. 


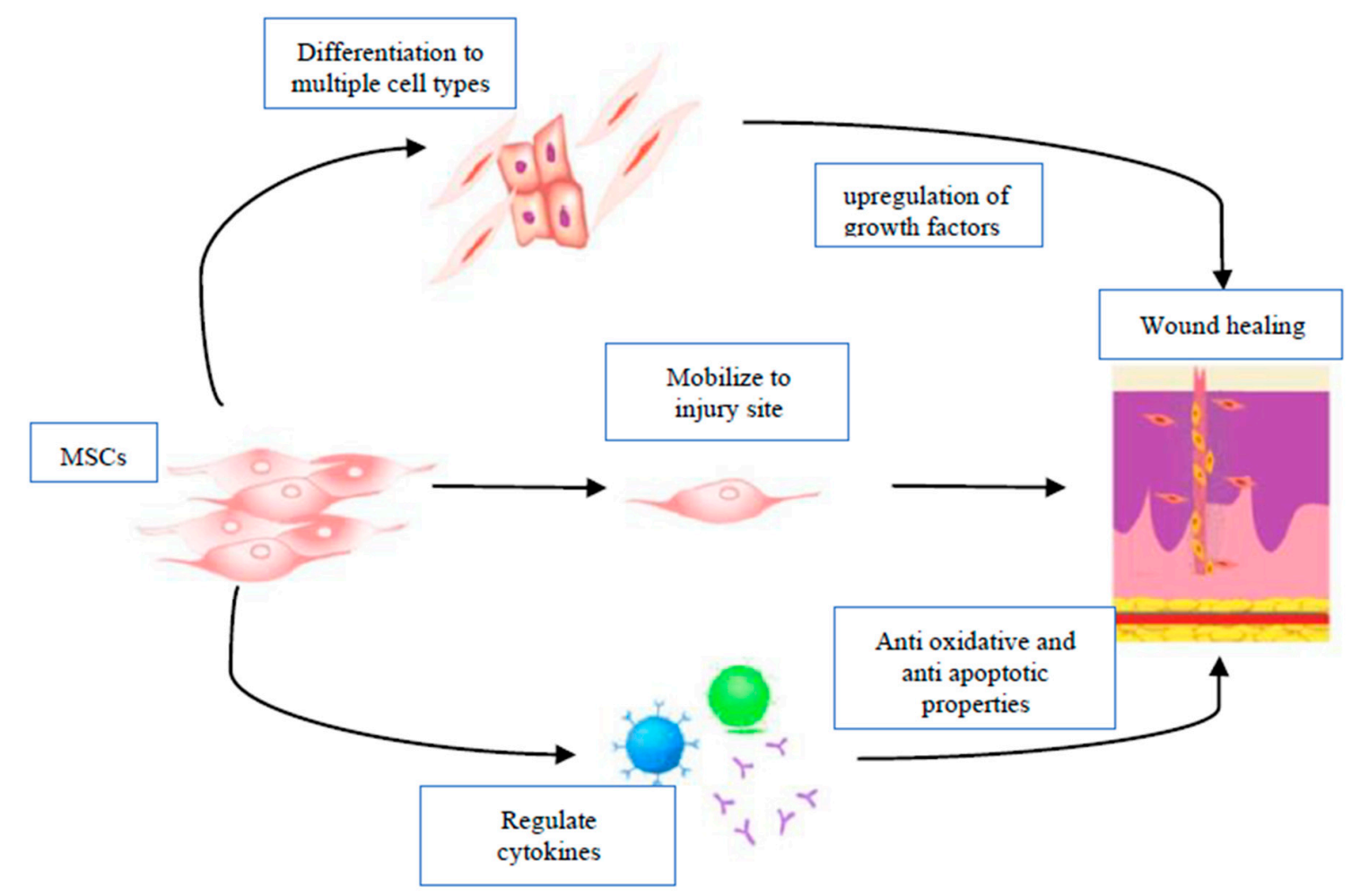

Figure 3. Mesenchymal stem cell (MSCs) mechanisms for wound repair. MSCs may facilitate wound healing through mobilization to wound site and differentiation to keratinocytes, dermal fibroblasts and other cell types. They also regulate the release of pro-inflammatory cytokines (IL-1 $\beta$, IFN- $\gamma$, IL-1RA, GM-CSF, and FLT-3L) and stimulate the release of growth factors (PDGF, TGF, FGF, EGF, KGF, VEGF).

\subsection{MSC Migration and Differentiation}

MSCs can render their effects in many ways, one of which is by mobilizing to the site of injury. Evidence for this was seen in two separate mouse wound models where the migration of bone-marrow-derived MSCs (BM-MSCs) to the wound site was tracked after intravenous administration [96,97]. This type of MSC migration and recruitment is based on their diverse chemokine receptor expression profile that promotes chemotaxis [98].

Furthermore, MSCs express and secrete paracrine factors that can activate repair and regeneration mechanisms and enhance cell survival. This has been established through studies using both MSCs as well as MSC-conditioned media [99]. Wharton's Jelly-derived MSC conditioned media has been shown to upregulate wound healing genes in skin fibroblasts in vitro as well as enhance their proliferation [100]. In line with these findings, BM-MSCs have also been reported to regulate dermal fibroblast proliferation and chemotaxis [101]. The paracrine effects have also been provided by in vivo results, wherein the administration of human adipose-derived stem cells (ASCs) into the sub eschar of mice with full-thickness burns wounds has resulted in the detection of mouse PPAR $\gamma$ and FABP-4, markers of adipogenesis and mature adipocytes, respectively, in the wound bed. It was proposed that human ASCs were exerting their effect by either recruiting mouse progenitors to the wound bed or inducing de novo adipogenesis from mouse progenitors [102]. Additionally, MSCs can secrete cytokines and growth factors, promote ECM rebuilding, angiogenesis, neovascularization and modulate the immune response [103].

Although not much is known about the MSCs' capability to promote healing through direct differentiation into different cell types at the wound site, there is some data available to support this. MSCs have been shown to have the capacity to differentiate into keratinocytes, endothelial cells and pericytes in mouse wound models [97]. 
Overall, these studies provide evidence of the capability of MSCs to not only mobilize to the site of injury, but also elicit their functions in the wound healing process through paracrine mechanisms and differentiation. Thus, MSCs have a potential use in the elderly to improve senescent skin cells' function and regenerate damaged tissues. These effects are depicted in Figure 3.

\subsection{MSCs and Collagen Deposition}

Stem cells can also contribute to ECM formation in wound repair through collagen deposition. Although Type I collagen typically exceeds Type III collagen in healthy skin, the remodeling of damaged skin initially depends on Type III collagen deposition [104]. ASCs can promote Type III collagen deposition in a model of rat burn wounds [104]. Additionally, bone-marrow-derived HSCs and MSCs contribute to the long-term collagen deposition during wound healing as they produce collagen Type III and I [105]. Furthermore, mice treated with BM-MSCs show a marked increase in the levels of the vascular endothelial growth factor (VEGF), a cytokine known to play a role in re-epithelialization and collagen deposition [96].

Interestingly, MSCs have also been proposed to play a role in mediating collagen deposition to prevent skin fibrosis which plays a role in scarring. In a model of bleomycin-induced dermal fibrosis, the administration of BM-MSCs resulted in the downregulation of heat shock protein 47 (HSP47) which is implicated in fibrosis [106].

\subsection{Angiogenesis and Vascularization}

MSCs also support wound healing through the promotion of vascularization/vasculogenesis (formation of new blood vessels) and angiogenesis (sprouting of pre-existing blood vessels) [107]. As mentioned earlier, MSC s' ability to regulate growth factors and cytokines can facilitate vascularization and angiogenesis [94]. For instance, placental MSCs have been shown to release proangiogenic molecules, such as VEGF, HGF, bFGF, TGF- $\beta$, and IGF-1 at bioactive levels in culture [108]. Furthermore, ASC-treated mice showed a significant increase in CD-31 expression at burn sites, indicating increased vascularization [102]. Additionally, the BM-MSC treatment of mice with burn injuries resulted in the elevation of VEGF and TGF- $\beta 1$, both of which are implicated in enhancing neovascularization [96]. These results were also echoed in rats with $30 \%$ total body surface area (TBSA) wounds, where human umbilical cord MSCs (UC-MSCs) transplantation increased VEGF levels [109]. The direct differentiation of MSCs has also been proposed to promote vascularization. Placental MSCs can gain endothelial-like morphology and express endothelial markers upon being cultured in endothelial-conditioned media. Direct de novo differentiation and paracrine mechanisms of such placental MSCs were proposed to be the causes of increased microvessel density in diabetic rat wounds [108]. Additionally, the endothelial transdifferentiation of MSCs at mouse wound sites were proposed to contribute to wound closures [97].

\subsection{Immunomodulatory Effects of Stem Cells}

Severe burns result in the release of several inflammatory cytokines which can lead to systemic inflammation [110]. They are associated with hypercatabolism and protein wasting which can progress to multi-organ failure, sepsis and even death, especially in the elderly population $[94,111,112]$. Some of these markers include tumor necrosis factor (TNF)- $\alpha$, IFN- $\gamma$, IL- $1 \beta$, IL-6, IL-8, IL-12, and IL-17 [94,95,111,113]. Modulating the inflammatory response is an important aspect of caring for burn patients. MSCs can attenuate this inflammatory response by regulating the cytokine profile post-burns, as well as controlling the cell population at the burn site.

Rats transplanted with UC-MSCs post-burn have a faster healing time which is accompanied by lower levels of TNF- $\alpha$ and IL-6 [114]. Similarly, in another study, rats transplanted with UC-MSCs post-burn experienced inflammation to a lesser extent and had lesser macrophage and neutrophil infiltration at the burn site. This was accompanied by a decrease in IL-1, IL-6, and TNF- $\alpha$ and an increase in the anti-inflammatory cytokines IL-10 and TSG-6 [109]. Moreover, the administration of UC- MSC-derived exosomes in rats with third-degree burns decreased the level of TNF- $\alpha$ and IL-1 $\beta$ 
which were elevated post-burn. There were also increased levels of IL-10 and decreased inflammatory neutrophil and macrophage content [115]. These results were confirmed in cell culture studies, wherein MSCs exposed to inflammatory burn-derived serum upregulated IL-10 expression [116]. Taken together, these findings are interesting, as they provide evidence in favor of MSCs being able to influence the expression of inflammatory cells and regulate the cytokine profile during injuries, especially in the elderly population where immune response is already impaired.

Furthermore, MSCs have also shown immunosuppressive potential in allografts. Pigs that received hemifacial allotransplants demonstrated increased allograft survival and delayed rejection with the administration of MSCs and Cyclosporin A. This group also showed decreased TNF- $\alpha$ and increased IL-10 in circulation two weeks post-transplantation. They also demonstrated a low population of IL-6 positive cells, and a significant increase in the CD25+ regulatory T-cell population [117]. Similarly, prolonged graft survival was seen in baboons that received skin grafts along with intravenous MSC administration [118]. Lastly, the injection of allogenic donor adipose tissue derived MSCs increased graft survival by an additional week in mice that received allogenic skin grafts [119].

These findings highlight the capability of MSCs to suppress allograft rejection by regulating the cytokine profile as well as the cell population. Studies like these are promising for the potential to pursue skin allografts with stem cells where the patient's own skin is not available for autografts due to poor healing or extensive burns and in elderly patients who are not good candidates for surgery due to their co-morbidities.

\section{Prospective on Elderly Burns}

\subsection{Stem Cell Role in Repairing Elderly Burn Wounds}

Superficial partial-thickness burns typically heal in 7-21 days without functional impairment or hypertrophic scarring [120]. The normal phases of wound healing are prolonged in the elderly [121]. Furthermore, individuals are in a chronic low-grade inflammatory state where inflammatory cytokines are increased $4 x$ than in the younger population even in the absence of infection or other diseases. Thus, their inflammatory response to burn injury is impaired, putting them at risk of various complications [68-70]. MSCs can modulate the inflammation by decreasing the circulating cytokines and other products of the inflammatory response in the elderly.

MSCs may also play a role in accelerating wound healing in the elderly by augmenting epidermal and dermal regeneration, by facilitating keratinocyte proliferation and migration and stimulating the production of dermal fibroblasts and collagen [122]. As described earlier, they also improve tissue circulation by increasing the number of new blood vessels [123-125]. Overall, MSCs lead to improved wound tensile strength, scar quality and tissue oxygenation. Furthermore, MSCs can influence and accelerate the already delayed phases of wound healing in the elderly and prevent it from becoming a deeper or a chronic non-healing wound by decreasing oxidative stress, activation of essential signaling pathways and attenuating the inflammatory response [126-128]. MSCs can inhibit the proliferation of T cells, TNF $\alpha$, IFN $\gamma$ and modulate cytokine secretion during the inflammatory phase of wound healing in the elderly. During the proliferative phase, MSCs augment keratinocyte, endothelial cell, fibroblast recruitment and differentiation and facilitate GF secretion. They also improve the collagen quality in the remodeling phase of wound healing in the elderly. This is shown in Figure 4. 


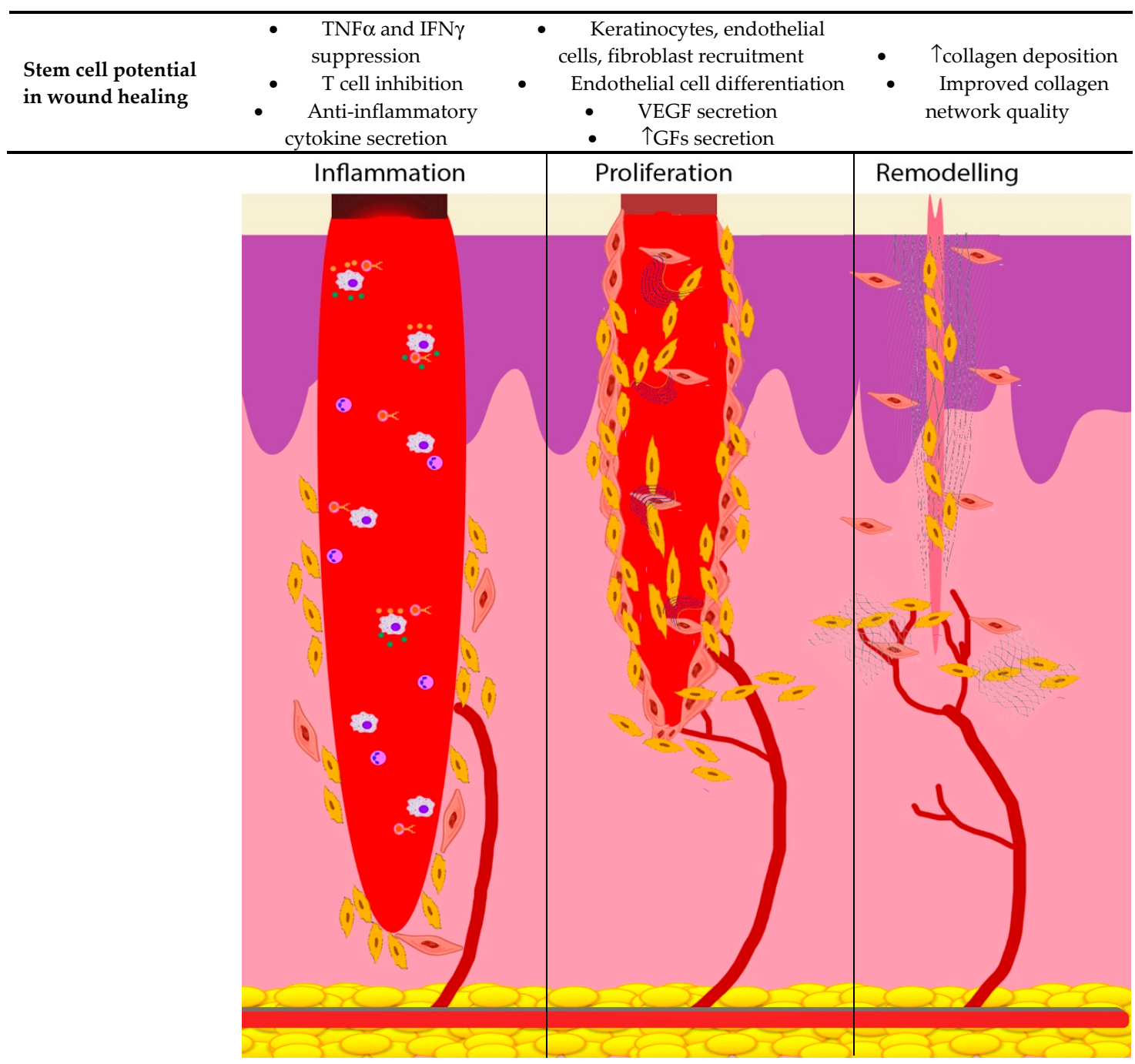

Figure 4. MSCs roles in each phase of the wound-healing process. Inflammatory phase, MSCs inhibit the proliferation of T cells, TNF $\alpha$, IFN $\gamma$ and modulate cytokine secretion. Proliferative phase, MSCs augment keratinocyte, endothelial cell, fibroblast recruitment and differentiation and facilitate GF secretion. Remodelling phase MSCs improve collagen quality.

BM-MSCs have been reported to successfully heal chronic wound ulcers of the lower extremities [129]. Alternatively, ASCs' potential to treat burn wounds and ulcers is being studied as they can be easily harvested as compared to BM-MSC [130]. UC-MSCs have been studied in animal models. Allogeneic UC-MSCs have shown low immunogenicity, in vitro and in a mouse model. IFN- $\gamma$ and TNF- $\alpha$ stimulation did not induce HLA-DR expression in these MSCs [131]. This low immunogenicity of cord-lining membrane MSCs (CL-MSCs) made it a remarkable candidate for clinical use which was recently described in a case report. CL-MSCs were applied topically using a fibrin sealant spray, followed by injection with commercially available MSCs on a patient with $>=70 \%$ TBSA that were mostly full-thickness. In addition to faster healing, no hypertrophic scarring or keloids were observed [132]. The ability to isolate viable MSCs from debrided burned skin is inspiring as it would overcome the need for harvesting the patient's own skin. Immunological reaction and rejection will be negligible since MSCs will come from the patient. Wound healing has been noted without adverse effects in mice and porcine wound models [91]. Studies as such provide evidence for the use of allogeneic MSCs for elderly burns, due to their regenerative capacity, low immunogenicity and lack of rejection potential [132]. 


\subsection{Skin Grafts and Donor Site Wound Repair in the Elderly Using Stem Cells}

Poor graft take, graft breakdown and delayed donor site healing are significant problems in elderly burns, putting patients at risk of infection.

Early burn wound excision and skin grafting is the standard in managing deep burn wounds. Skin grafting involves removing healthy skin from one area of the body and transplanting it onto a wound [133]. This can be challenging in the elderly, due to their impaired wound healing, poor microvasculature and high susceptibility to infection. Furthermore, harvesting the patient's own skin may lead to an unintentional new full-thickness wound [134]. The potential role of MSCs in skin grafts is seen in a Phase I Clinical Trial (NCT02104713), wherein BM-MSCs therapy was used on patients $>18$ years old with deep burns, followed by the application of a split-thickness skin graft. The initial results showed improved graft take and skin regeneration, limited scarring and contracture [135]. The results show the potential role of MSCs in the elderly to enhance the results of split-thickness skin grafting.

Donor site wounds continue to be an area of concern in elderly burns, which can be attributed to a thin dermis and longer healing time of harvest sites [136]. Donor site wounds are the wounds made when the patient's own healthy skin is removed for split thickness skin grafting. MSCs have the potential to bypass the considerable morbidity associated with donor sites in the elderly by influencing and accelerating the activation, migration and proliferation of different cells involved in the normal phases of wound healing, thereby improving re-epithelialization [117-119].

Various skin substitutes have been explored as alternative strategies to circumvent the use of skin grafts and avoid donor site complications. Examples of skin substitutes range from artificial substitutes, human-derived substitutes to porcine substitutes [137]. The types of skin substitutes that are being studied and used range from dermal substitutes and epidermal substitutes to dermal-epidermal substitutes [138].

The use of MSCs with skin substitutes may have a future role as an alternative to skin grafts [139,140]. In an in vitro model, human umbilical vein endothelial cells (HUVECs), ASCs, and fibroblasts seeded onto a fibrin matrix were able to promote a capillary-like structure in which cells were positive for endothelial markers [141]. Furthermore, skin substitutes have also been tested in vivo. Integra ${ }^{\circledR}$ that is transplanted onto mouse wounds along with MSCs, showed significant vascular density [142]. Porcine skin substitutes soaked with MSCs and treated with fibroblast growth factors were able to accelerate wound healing and re-epithelialization in a rat wound model [143]. ASCs or human fetal fibroblasts seeded onto a human amniotic membrane were also capable of lowering inflammation when transplanted onto rat burns [139]. Methodologies as such, have also been applied in clinical settings, wherein MSCs seeded onto an artificial dermis were used to treat wounds [140]. The additional benefit of using skin substitutes is that it eliminates the need for harvesting donor skin, thus avoiding the consequences associated with it.

\section{Conclusions}

As the elderly population continues to increase, so are the cases of elderly burn patients. An increase in the number of elderly burns is significant since wound healing in the elderly is delayed, leading to morbidities, prolonged hospital stays and mortalities. Important changes in the aging skin render it more susceptible to deeper burns, ineffective wound healing and inadequate immunologic response. Based on their relatively easy isolation, potential for proliferation and differentiation and lack of immunogenicity MSCs may play a role in improving burn wound healing in the elderly. They facilitate healing in the already delayed phases of wound healing, modify the impaired immune response, stimulate and augment growth factor secretion and cell proliferation. The use of MSCs has an important prospective role in the elderly population. They can be used to accelerate healing in superficial partial thickness burns and donor site wounds, improve graft take and prevent graft breakdown. This can lead to an overall better quality of life, shorter hospitalization and decreased cost of care. 
Further studies are needed to determine the optimal routes of stem cell administration, optimal cell dose to show definitive effectiveness and the fate of the cells after administration, particularly in the elderly.

Funding: The authors declare that they have no known competing financial interests or personal associations that could have appeared to influence the work reported in this paper.

Conflicts of Interest: The authors declare no conflict of interest.

\section{References}

1. Parachute. The Cost of Injury in Canada; Parachute: Toronto, ON, Canada, 2015; pp. 1-164.

2. American Burn Association. National Burn Repository 2019 Update: Report of Data from 2009 to 2018; American Burn Association: Chicago, IL, USA, 2019.

3. Ahn, C.S.; Maitz, P.K.M. The true cost of burn. Burns 2012, 38, 967-974. [CrossRef] [PubMed]

4. Eser, T.; Kavalci, C.; Aydogan, C.; Kayipmaz, A.E. Epidemiological and cost analysis of burn injuries admitted to the emergency department of a tertiary burn center. SpringerPlus 2016, 5, 1411. [CrossRef] [PubMed]

5. Endo, A.; Shiraishi, A.; Otomo, Y.; Fushimi, K.; Murata, K. Volume-outcome relationship on survival and cost benefits in severe burn injury: A retrospective analysis of a Japanese nationwide administrative database. J. Intensive Care 2019, 7, 7. [CrossRef] [PubMed]

6. Seo, D.K.; Kym, D.; Yim, H.; Yang, H.T.; Cho, Y.S.; Kim, J.H.; Hur, J.; Chun, W. Epidemiological trends and risk factors in major burns patients in South Korea: A 10-year experience. Burns 2015, 41, 181-187. [CrossRef]

7. Scott-Conner, C.; Meydrech, E.; Wheeler, W.; Coil, J., Jr. Quantitation of Rate of Wound Closure and the Prediction of Death Following Major Burns. Burns Incl. Therm. Inj. 1988, 14, 373-378. [CrossRef]

8. Jeschke, M.G.; Pinto, R.; Costford, S.R.; Amini-Nik, S. Threshold age and burn size associated with poor outcomes in the elderly after burn injury. Burns 2016, 42, 276-281. [CrossRef]

9. Maxson, S.; Lopez, E.A.; Yoo, D.; Danilkovitch-Miagkova, A.; LeRoux, M.A. Concise Review: Role of Mesenchymal Stem Cells in Wound Repair. Stem Cells Transl. Med. 2012, 1, 142-149. [CrossRef]

10. Du, X. 3D Bio-Printing Review. In Proceedings of the The 5th Annual International Conference on Material Science and Environmental Engineering (MSEE2017); IOP Publishing: Xiamen, China, 2017; Volume 301, p. 012023.

11. Infographic: Canada's Seniors Population Outlook: Uncharted Territory. Available online: https://www.cihi. ca/en/infographic-canadas-seniors-population-outlook-uncharted-territory (accessed on 3 March 2020).

12. Hu, M.S.; Borrelli, M.R.; Lorenz, H.P.; Longaker, M.T.; Wan, D.C. Mesenchymal Stromal Cells and Cutaneous Wound Healing: A Comprehensive Review of the Background, Role, and Therapeutic Potential. Stem Cells Int. 2018, 2018, 6901983. [CrossRef]

13. Yamaguchi, Y.; Yoshikawa, K. Cutaneous Wound Healing: An Update. J. Dermatol. 2001, 28, 521-534. [CrossRef]

14. Isakson, M.; de Blacam, C.; Whelan, D.; McArdle, A.; Clover, A.J.P. Mesenchymal Stem Cells and Cutaneous Wound Healing: Current Evidence and Future Potential. Stem Cells Int. 2015, 2015, 831095. [CrossRef]

15. ClinicalTrials.gov. Bethesda (MD): National Library of Medicine (US). 2000 Feb 29. Identifier NCT01443689, Allogenic Stem Cell Therapy in Patients with Acute Burn. 2006 September 30 [Update 2012 November 28]. Available online: https://clinicaltrials.gov/ct2/show/NCT01443689?term=stem+cells\&cond=burn\&draw=3\& rank=1 (accessed on 3 March 2020).

16. ClinicalTrials.gov. Bethesda (MD): National Library of Medicine (US). 2000 Feb 29. Identifier NCT04235296, Mesenchymal Stem Cell Conditioned Medium-derived Pleiotropic Factor in Treating Residual Burn Wound. 2020 January 21 [Update 2020 May 12]. Available online: https://linicaltrials.gov/ct2/show/NCT04235296? term $=$ stem+cells\&cond=burn\&draw $=3 \&$ rank $=2$ (accessed on 3 March 2020).

17. ClinicalTrials.gov. Bethesda (MD): National Library of Medicine (US). 2000 Feb 29. Identifier NCT02104713, Stem Cell Therapy to Improve Burn Wound Healing. 2014 April 4 [Update 2020 April 30]. Available online: https://clinicaltrials.gov/ct2/show/NCT02104713?term=stem+cells\&cond=burn\&draw=3\&rank=3 (accessed on 3 March 2020). 
18. ClinicalTrials.gov. Bethesda (MD): National Library of Medicine (US). 2000 Feb 29. Identifier NCT03686449, Autologous Keratinocyte Suspension Versus Adipose-Derived Stem Cell-Keratinocyte Suspension for Post-Burn Raw Area. 2018 September 27 [Update 2020 May 12]. Available online: https:/clinicaltrials.gov/ ct2/show/NCT03686449?term=stem+cells\&cond=burn\&draw=3\&rank=5 (accessed on 3 March 2020).

19. ClinicalTrials.gov. Bethesda (MD): National Library of Medicine (US). 2000 Feb 29. Identifier NCT02394873, A Study to Evaluate the Safety of ALLO-ASC-DFU in the Subjects with Deep Second-Degree Burn Wound. 2015 March 20 [Update 2015 December 30]. Available online: https://clinicaltrials.gov/ct2/show/NCT02394873? term $=$ stem + cells\&cond=burn\&draw=3\&rank=10 (accessed on 3 March 2020).

20. ClinicalTrials.gov. Bethesda (MD): National Library of Medicine (US). 2000 Feb 29. Identifier NCT03113747, Allogeneic ADSCs and Platelet-Poor Plasma Fibrin Hydrogel to Treat the Patients with Burn Wounds (ADSCs-BWs) (ADSCs-BWs). 2017 April 14 [2017 April 26]. Available online: https://clinicaltrials.gov/ct2/ show/NCT03113747?term=stem+cells\&cond=burn\&draw=3\&rank=13 (accessed on 3 March 2020).

21. Zouboulis, C.C.; Makrantonaki, E. Clinical aspects and molecular diagnostics of skin aging. Clin. Dermatol. 2011, 29, 3-14. [CrossRef] [PubMed]

22. Farage, M.A.; Miller, K.W.; Elsner, P.; Maibach, H.I. Characteristics of the Aging Skin. Adv. Wound Care New Rochelle 2013, 2, 5-10. [CrossRef] [PubMed]

23. Jeschke, M.G.; Peck, M.D. Burn Care of the Elderly. J. Burn Care Res. 2017, 38, e625-e628. [CrossRef] [PubMed]

24. Hubbard, B.A.; Unger, J.G.; Rohrich, R.J. Reversal of Skin Aging with Topical Retinoids. Plast. Reconstr. Surg. 2014, 133, 481e-490e. [CrossRef]

25. Gosain, A.; DiPietro, L.A. Aging and Wound Healing. World J. Surg. 2004, 28, 321-326. [CrossRef]

26. Abu-Sittah, G.; Chahine, F.; Janom, H. Management of Burns in the Elderly. Ann. Burns Fire Disasters 2016, 29, 249-254.

27. Kligman, A.; Balin, A. Aging of Human Skin; Raven Press: New York, NY, USA, 1989.

28. Fore, J. A Review of Skin and the Effects of Aging on Skin Structure and Function. Ostomy Wound Manag. 2006, 52, 24-35.

29. Elias, P.M. Stratum corneum acidification: How and why? Exp. Dermatol. 2015, 24, 179-180. [CrossRef]

30. Jia, Q.; Nash, J. Pathology of Aging Skin. In Textbook of Aging Skin; Springer: Berlin/Heidelberg, Germany, 2017.

31. Karimipour, D.J.; Rittié, L.; Hammerberg, C.; Min, V.K.; Voorhees, J.J.; Orringer, J.S.; Sachs, D.L.; Hamilton, T.; Fisher, G.J. Molecular Analysis of Aggressive Microdermabrasion in Photoaged Skin. Arch. Dermatol. 2009, 145, 1114-1122. [CrossRef]

32. Calleja-Agius, J.; Muscat-Baron, Y.; Brincat, M. Skin aging. Menopause Int. 2007, 13, 60-64. [CrossRef]

33. Grey, J.E.; Harding, K.G.; Enoch, S. ABC of wound healing: Pressure ulcers. BMJ 2006, 332, $472-475$. [CrossRef] [PubMed]

34. Park, J.E.; Barbul, A. Understanding the role of immune regulation in wound healing. Am. J. Surg. 2004, 187, 11S-16S. [CrossRef]

35. Jiang, J.; Fisher, E.M.; Murasko, D.M. CD8 T cell responses to influenza virus infection in aged mice. Ageing Res. Rev. 2011, 10, 422-427. [CrossRef] [PubMed]

36. Alonso-Fernández, P.; De la Fuente, M. Role of the Immune System in Aging and Longevity. Curr. Aging Sci. 2011, 4, 78-100. [CrossRef]

37. Huertas, A.; Schmelzer, C.; Hoehenwarter, W.; Heyroth, F.; Heinz, A. Molecular level insights into aging processes of skin elastin. Biochimie 2016. [CrossRef]

38. Zhang, S.; Duan, E. Fighting against Skin Aging: The Way from Bench to Bedside. Cell Transplant. 2018, 27, 729-738. [CrossRef]

39. Yaar, M.; Gilchrest, B. Skin Aging: Postulated Mechanisms and Consequent Changes in Structure and Function. Clin. Geriatr. Med. 2001, 17, 617-630. [CrossRef]

40. Yaar, M.; Eller, M.S.; Gilchrest, B.A. Fifty Years of Skin Aging. J. Investig. Dermatol. Symp. Proc. 2002, 7, 51-58. [CrossRef]

41. Sørensen, L.T. Effect of lifestyle, gender and age on collagen formation and degradation. Hernia 2006, 10, 456-461. [CrossRef]

42. Rani, M.; Schwacha, M.G. Aging and the Pathogenic Response to Burn. Aging Dis. 2012, 3, 171-180.

43. Parihar, A.; Parihar, M.S.; Milner, S.; Bhat, S. Oxidative stress and anti-oxidative mobilization in burn injury. Burns 2008, 34, 6-17. [CrossRef] [PubMed] 
44. Gutteridge, J.; Halliwell, B. Iron Toxicity and Oxygen Radicals. Baillières Clin. Haematol. 1989, 2, $195-256$. [CrossRef]

45. Sies, H. Strategies of antioxidant defense. Eur. J. Biochem. 1993, 215, 213-219. [CrossRef] [PubMed]

46. Kammeyer, A.; Luiten, R.M. Oxidation events and skin aging. Ageing Res. Rev. 2015, 21, 16-29. [CrossRef]

47. Aust, S.; Thomas, C.; Morehouse, L.; Saito, M.; Bucher, J. Active oxygen and toxicity. Adv. Exp. Med. Biol. 1986, 197, 513-526. [CrossRef]

48. Guemouri, L.; Artur, Y.; Herbeth, B.; Jeandel, C.; Cuury, G.; Siest, G. Biological Variability of Superoxide Dismutase, Glutathione Peroxidase, and Catalase in Blood. Clin. Chem. 1991, 37, 1932-1937. [CrossRef]

49. Poljšak, B.; Dahmane, R.G.; Godić, A. Intrinsic skin aging: The role of oxidative stress. Acta Dermatovenerol. Alp. Pannonica Adriat. 2012, 21,33-36. [CrossRef]

50. Liguori, I.; Russo, G.; Curcio, F.; Bulli, G.; Aran, L.; Della-Morte, D.; Gargiulo, G.; Testa, G.; Cacciatore, F.; Bonaduce, D.; et al. Oxidative stress, aging, and diseases. Clin. Interv. Aging 2018, 13, 757-772. [CrossRef] [PubMed]

51. Park, C.; Larsson, N. Mitochondrial DNA mutations in disease and aging. J. Cell Biol. 2011, 193, 809-818. [CrossRef]

52. Mantel, C.R.; O’Leary, H.A.; Chitteti, B.R.; Huang, X.; Cooper, S.; Hangoc, G.; Brustovetsky, N.; Srour, E.F.; Lee, M.R.; Messina-Graham, S.; et al. Enhancing hematopoietic stem cell transplantation efficacy by mitigating oxygen shock. Cell 2015, 161, 1553-1565. [CrossRef]

53. Garcia-Prat, L.; Martinez-Vicente, M.; Perdiguero, E.; Ortet, L.; Rodriguez-Ubreva, J.; Rebollo, E.; Ruiz-Bonilla, V.; Gutarra, S.; Ballestar, E.; Serrano, A.; et al. Autophagy maintains stemness by preventing senescence. Nature 2016, 529, 37-42. [CrossRef] [PubMed]

54. Kosmadaki, M.G.; Gilchrest, B.A. The role of telomeres in skin aging/photoaging. Micron 2004, 35, 155-159. [CrossRef] [PubMed]

55. Wright, W.E.; Shay, J.W. Cellular senescence as a tumor-protection mechanism: The essential role of counting. Curr. Opin. Genet. Dev. 2001, 11, 98-103. [CrossRef]

56. Richter, T.; von Zglinicki, T. A continuous correlation between oxidative stress and telomere shortening in fibroblasts. Exp. Gerontol. 2007, 42, 1039-1042. [CrossRef] [PubMed]

57. Serra, V.; von Zglinicki, T.; Lorenz, M.; Saretzki, G. Extracellular Superoxide Dismutase Is a Major Antioxidant in Human Fibroblasts and Slows Telomere Shortening. J. Biol. Chem. 2003, 278, 6824-6830. [CrossRef]

58. Buckingham, E.M.; Klingelhutz, A.J. The role of telomeres in the ageing of human skin: Telomeres and skin ageing. Exp. Dermatol. 2011, 20, 297-302. [CrossRef]

59. Rinnerthaler, M.; Bischof, J.; Streubel, M.; Trost, A.; Richter, K. Oxidative Stress in Aging Human Skin. Biomolecules 2015, 5, 545-589. [CrossRef]

60. Panich, U.; Sittithumcharee, G.; Rathviboon, N.; Jirawatnotai, S. Ultraviolet Radiation-Induced Skin Aging: The Role of DNA Damage and Oxidative Stress in Epidermal Stem Cell Damage Mediated Skin Aging. Stem Cells Int. 2016, 2016, 7370642. [CrossRef]

61. Ning, M.S.; Andl, T. Control by a hair's breadth: The role of microRNAs in the skin. Cell. Mol. Life Sci. 2013, 70, 1149-1169. [CrossRef]

62. Van Deursen, J. The role of senescent cells in aging. Nature 2014, 509, 439-446. [CrossRef]

63. McHugh, D.; Gil, J. Senescence and aging: Causes, consequences, and therapeutic avenues. J. Cell Biol. 2018, 217, 65-77. [CrossRef] [PubMed]

64. Toutfaire, M.; Bauwens, E.; Debacq-Chainiaux, F. The impact of cellular senescence in skin ageing: A notion of mosaic and therapeutic strategies. Biochem Pharm. 2017, 142, 1-12. [CrossRef] [PubMed]

65. Demaria, M.; Ohtani, N.; Youssef, S.; Rodier, F.; Toussaint, W.; Mitchell, J.; Laberge, R.M.; Vijg, J.; Van Steeg, H.; Dollé, M.; et al. An essential role for senescent cells in optimal wound healing through secretion of PDGF-AA. Dev. Cell 2014, 31, 722-733. [CrossRef]

66. Wang, A.; Dreesen, O. Biomarkers of Cellular Senescence and Skin aging. Front. Genet. 2019, 9, 247. [CrossRef] [PubMed]

67. Swift, M.E.; Burns, A.L.; Gray, K.L.; DiPietro, L.A. Age-Related Alterations in the Inflammatory Response to Dermal Injury. J. Investig. Dermatol. 2001, 117, 1027-1035. [CrossRef] [PubMed]

68. Franceschi, C.; Bonafè, M.; Valensin, S.; Olivieri, F.; De Luca, M.; Ottaviani, E.; De Benedictis, G. Inflamm-aging: An Evolutionary Perspective on Immunosenescence. Ann. N. Y. Acad. Sci. 2000, 908, 244-254. [CrossRef] 
69. Nomellini, V.; Gomez, C.R.; Gamelli, R.L.; Kovacs, E.J. Aging and Animal Models of Systemic Insult: Trauma, Burn, and Sepsis. Shock 2009, 31, 11-20. [CrossRef]

70. Stanojcic, M.; Chen, P.; Xiu, F.; Jeschke, M.G. Impaired Immune Response in Elderly Burn Patients: New Insights Into the Immune-senescence Phenotype. Ann. Surg. 2016, 264, 195-202. [CrossRef]

71. Franceschi, C.; Campisi, J. Chronic Inflammation (Inflammaging) and Its Potential Contribution to Age-Associated Diseases. J. Gerontol. A Biol. Sci. Med. Sci. 2014, 69, S4-S9. [CrossRef]

72. Ferrucci, L.; Fabbri, E. Inflammageing: Chronic inflammation in ageing, cardiovascular disease, and frailty. Nat. Rev. Cardiol. 2018, 15, 505-522. [CrossRef]

73. Tredget, E.E.; Yu, Y.M. The metabolic effects of thermal injury. World J. Surg. 1992, 16, 68-79. [CrossRef]

74. Till, G.; Hatherill, J.R.; Tourtellotte, W.; Lutz, M.; Ward, P.A. Lipid Peroxidation and Acute Lung Injury After Thermal Trauma to Skin. Evidence of a Role for Hydroxyl Radical. Am. J. Pathol. 1985, 119, 376-384. [PubMed]

75. Haycoskl, J.W.; Ralstox, R.; Morris, B.; Freedlander, E.; MasNeil', S. Oxidative damage to protein and alterations to antioxidant levels in human cutaneous thermal injury. Burns 1997, 23, 533-540. [CrossRef]

76. Horton, J.W. Free radicals and lipid peroxidation mediated injury in burn trauma: The role of antioxidant therapy. Toxicology 2003, 189, 75-88. [CrossRef]

77. O'Toole, E.; Goel, M.; Woodley, D. Hydrogen Peroxide Inhibits Human Keratinocyte Migration. Search Results Web Result Site Links Dermatol. Surg. 1996, 22, 525-529. [CrossRef] [PubMed]

78. Lindblom, L.; Cassuto, J.; Yregård, L.; Mattsson, U.; Tarnow, P.; Sinclair, R. Importance of nitric oxide in the regulation of burn oedema, proteinuria and urine output. Burns 2000, 26, 13-17. [CrossRef]

79. Schwacha, M.; Anantha Samy, T.; Catania, R.; Chaudry, I. Thermal injury alters macrophage responses to prostaglandin E2: Contribution to the enhancement of inducible nitric oxide synthase activity. J. Leukoc. Biol. 1998, 64, 740-746. [CrossRef]

80. Huang, F.; Niedbala, W.; Wei1, X.-Q.; Xu, D.; Feng, G.; Robinson, J.; Lam, C.; Liew, F. Nitric oxide regulates Th1 cell development through the inhibition of IL-12 synthesis by macrophages. Eur. J. Immunol. 1998, 28, 4062-4070. [CrossRef]

81. Kao, C.; Garner, W. Acute Burns. Plast. Reconstr. Surg. 2000, 105, 2482-2492. [CrossRef]

82. Grimble, R.F. Inflammatory response in the elderly. Curr. Opin. Clin. Nutr. Metab. Care 2003, 6, 21-29. [CrossRef]

83. Lundgren, R.S.; Kramer, C.B.; Rivara, F.P.; Wang, J.; Heimbach, D.M.; Gibran, N.S.; Klein, M.B. Influence of Comorbidities and Age on Outcome Following Burn Injury in Older Adults. J. Burn Care Res. 2009, 30, 307-314. [CrossRef] [PubMed]

84. Alvarez, C.V.; Garcia-Lavandeira, M.; Garcia-Rendueles, M.E.R.; Diaz-Rodriguez, E.; Garcia-Rendueles, A.R.; Perez-Romero, S.; Vila, T.V.; Rodrigues, J.S.; Lear, P.V.; Bravo, S.B. Defining stem cell types: Understanding the therapeutic potential of ESCs, ASCs, and iPS cells. J. Mol. Endocrinol. 2012, 49, R89-R111. [CrossRef] [PubMed]

85. Zakrzewski, W.; Dobrzyński, M.; Szymonowicz, M.; Rybak, Z. Stem cells: Past, present, and future. Stem Cell Res. Ther. 2019, 10, 1-22. [CrossRef] [PubMed]

86. Romito, A.; Cobellis, G. Pluripotent Stem Cells: Current Understanding and Future Directions. Stem Cells Int. 2016, 2016, 9451492. [CrossRef] [PubMed]

87. Mirzaei, H.; Sahebkar, A.; Sichani, L.S.; Moridikia, A.; Nazari, S.; Sadri Nahand, J.; salehi, H.; Stenvang, J.; Masoudifar, A.; Mirzaei, H.R.; et al. Therapeutic application of multipotent stem cells. J. Cell. Physiol. 2018, 233, 2815-2823. [CrossRef]

88. Mahla, R.S. Stem Cells Applications in Regenerative Medicine and Disease Therapeutics. Int. J. Cell Biol. 2016, 2016, 6940283. [CrossRef]

89. Ullah, I.; Subbarao, R.B.; Rho, G.J. Human mesenchymal stem cells-Current trends and future prospective. Biosci. Rep. 2015, 35. [CrossRef]

90. Dominici, M.; Le Blanc, K.; Mueller, I.; Slaper-Cortenbach, I.; Marini, F.C.; Krause, D.S.; Deans, R.J.; Keating, A.; Prockop, D.J.; Horwitz, E.M. Minimal criteria for defining multipotent mesenchymal stromal cells. The International Society for Cellular Therapy position statement. Cytotherapy 2006, 8, 315-317. [CrossRef]

91. Amini-Nik, S.; Dolp, R.; Eylert, G.; Datu, A.-K.; Parousis, A.; Blakeley, C.; Jeschke, M.G. Stem cells derived from burned skin-The future of burn care. EBioMedicine 2018, 37, 509-520. [CrossRef] 
92. Han, Y.; Li, X.; Zhang, Y.; Han, Y.; Chang, F.; Ding, J. Mesenchymal Stem Cells for Regenerative Medicine. Cells 2019, 8, 886. [CrossRef]

93. Rodgers, K.; Jadhav, S.S. The application of mesenchymal stem cells to treat thermal and radiation burns. Adv. Drug Deliv. Rev. 2018, 123, 75-81. [CrossRef] [PubMed]

94. Butler, K.L.; Goverman, J.; Ma, H.; Fischman, A.; Yu, Y.-M.; Bilodeau, M.; Rad, A.M.; Bonab, A.A.; Tompkins, R.G.; Fagan, S.P. Stem Cells and Burns: Review and Therapeutic Implications. J. Burn Care Res. 2010, 31, 874-881. [CrossRef] [PubMed]

95. Maranda, E.; Rodriguez-Menocal, L.; Badiavas, E. Role of Mesenchymal Stem Cells in Dermal Repair in Burns and Diabetic Wounds. Curr. Stem Cell Res. Ther. 2017, 12, 61-70. [CrossRef]

96. Oh, E.J.; Lee, H.W.; Kalimuthu, S.; Kim, T.J.; Kim, H.M.; Baek, S.H.; Zhu, L.; Oh, J.M.; Son, S.H.; Chung, H.Y.; et al. In vivo migration of mesenchymal stem cells to burn injury sites and their therapeutic effects in a living mouse model. J. Control. Release 2018, 279, 79-88. [CrossRef] [PubMed]

97. Sasaki, M.; Abe, R.; Fujita, Y.; Ando, S.; Inokuma, D.; Shimizu, H. Mesenchymal Stem Cells Are Recruited into Wounded Skin and Contribute to Wound Repair by Transdifferentiation into Multiple Skin Cell Type. J. Immunol. 2008, 180, 2581-2587. [CrossRef] [PubMed]

98. Ringe, J.; Strassburg, S.; Neumann, K.; Endres, M.; Notter, M.; Burmester, G.-R.; Kaps, C.; Sittinger, M. Towards in situ tissue repair: Human mesenchymal stem cells express chemokine receptors CXCR1, CXCR2 and CCR2, and migrate upon stimulation with CXCL8 but not CCL. J. Cell. Biochem. 2007, 101, 135-146. [CrossRef]

99. Hocking, A.M.; Gibran, N.S. Mesenchymal stem cells: Paracrine signaling and differentiation during cutaneous wound repair. Exp. Cell Res. 2010, 316, 2213-2219. [CrossRef]

100. Arno, A.I.; Amini-Nik, S.; Blit, P.H.; Al-Shehab, M.; Belo, C.; Herer, E.; Tien, C.; Jeschke, M.G. Human Wharton's jelly mesenchymal stem cells promote skin wound healing through paracrine signaling. Stem Cell Res. Ther. 2014, 5, 28. [CrossRef]

101. Smith, A.N.; Willis, E.; Chan, V.T.; Muffley, L.A.; Isik, F.F.; Gibran, N.S.; Hocking, A.M. Mesenchymal stem cells induce dermal fibroblast responses to injury. Exp. Cell Res. 2010, 316, 48-54. [CrossRef]

102. Bliley, J.M.; Argenta, A.; Satish, L.; McLaughlin, M.M.; Dees, A.; Tompkins-Rhoades, C.; Marra, K.G.; Rubin, J.P. Administration of adipose-derived stem cells enhances vascularity, induces collagen deposition, and dermal adipogenesis in burn wounds. Burns 2016, 42, 1212-1222. [CrossRef]

103. Baraniak, P.R.; McDevitt, T.C. Stem cell paracrine actions and tissue regeneration. Regen. Med. 2010, 5, 121-143. [CrossRef] [PubMed]

104. Franck, C.L.; Senegaglia, A.C.; Leite, L.M.B.; de Moura, S.A.B.; Francisco, N.F.; Ribas Filho, J.M. Influence of Adipose Tissue-Derived Stem Cells on the Burn Wound Healing Process. Stem Cells Int. 2019, 2019, 2340725. [CrossRef] [PubMed]

105. Fathke, C.; Wilson, L.; Hutter, J.; Kapoor, V.; Smith, A.; Hocking, A.; Isik, F. Contribution of Bone Marrow-Derived Cells to Skin: Collagen Deposition and Wound Repair. Stem Cells 2004, 22, 812-822. [CrossRef] [PubMed]

106. Wu, Y.; Huang, S.; Enhe, J.; Ma, K.; Yang, S.; Sun, T.; Fu, X. Bone marrow-derived mesenchymal stem cell attenuates skin fibrosis development in mice: A cell-based therapy to alleviating skin fibrosis. Int. Wound J. 2014, 11, 701-710. [CrossRef]

107. Watt, S.M.; Gullo, F.; van der Garde, M.; Markeson, D.; Camicia, R.; Khoo, C.P.; Zwaginga, J.J. The angiogenic properties of mesenchymal stem/stromal cells and their therapeutic potential. Br. Med. Bull. 2013, 108, 25-53. [CrossRef]

108. Kong, P.; Xie, X.; Li, F.; Liu, Y.; Lu, Y. Placenta mesenchymal stem cell accelerates wound healing by enhancing angiogenesis in diabetic Goto-Kakizaki (G.K.) rats. Biochem. Biophys. Res. Commun. 2013, 438, 410-419. [CrossRef]

109. Liu, L.; Yu, Y.; Hou, Y.; Chai, J.; Duan, H.; Chu, W.; Zhang, H.; Hu, Q.; Du, J. Human Umbilical Cord Mesenchymal Stem Cells Transplantation Promotes Cutaneous Wound Healing of Severe Burned Rats. PLoS ONE 2014, 9, e88348. [CrossRef]

110. Ipaktchi, K.; Mattar, A.; Niederbichler, A.D.; Hoesel, L.M.; Vollmannshauser, S.; Hemmila, M.R.; Su, G.L.; Remick, D.G.; Wang, S.C.; Arbabi, S. Attenuating Burn Wound Inflammatory Signaling Reduces Systemic Inflammation and Acute Lung Injury. J. Immunol. 2006, 177, 8065-8071. [CrossRef] 
111. Gauglitz, G.G.; Song, J.; Herndon, D.N.; Finnerty, C.C.; Boehning, D.; Barral, J.M.; Jeschke, M.G. Characterization of the inflammatory response during acute and post-acute phases after severe burn. Shock 2008, 30, 503-507. [CrossRef]

112. Schwacha, M.G.; Thobe, B.M.; Daniel, T.; Hubbard, W.J. Impact of Thermal Injury on Wound Infiltration and the Dermal Inflammatory Response. J. Surg. Res. 2010, 158, 112-120. [CrossRef]

113. Kim, A.; Lang, T.; Xue, M.; Wijewardana, A.; Jackson, C.; Vandervord, J. The Role of Th-17 Cells and $\gamma \delta$ T-Cells in Modulating the Systemic Inflammatory Response to Severe Burn Injury. Int. J. Mol. Sci. 2017, 18, 758. [CrossRef] [PubMed]

114. Zhang, J.; La, X.; Fan, L.; Li, P.; Yu, Y.; Huang, Y.; Ding, J.; Xing, Y. Immunosuppressive effects of mesenchymal stem cell transplantation in rat burn models. Int. J. Clin. Exp. Pathol. 2015, 8, 5129-5136. [PubMed]

115. Li, X.; Liu, L.; Yang, J.; Yu, Y.; Chai, J.; Wang, L.; Ma, L.; Yin, H. Exosome Derived from Human Umbilical Cord Mesenchymal Stem Cell Mediates MiR-181c Attenuating Burn-induced Excessive Inflammation. EBioMedicine 2016, 8, 72-82. [CrossRef] [PubMed]

116. Yagi, H.; Soto-Gutierrez, A.; Kitagawa, Y.; Tilles, A.W.; Tompkins, R.G.; Yarmush, M.L. Bone Marrow Mesenchymal Stromal Cells Attenuate Organ Injury Induced by LPS and Burn. Cell Transplant. 2010, 19, 823-830. [CrossRef]

117. Kuo, Y.-R.; Chen, C.-C.; Goto, S.; Huang, Y.-T.; Wang, C.-T.; Tsai, C.; Chen, C.-L. Immunomodulatory Effects of Bone Marrow-Derived Mesenchymal Stem Cells in a Swine Hemi-Facial Allotransplantation Model. PLoS ONE 2012, 7, e35459. [CrossRef] [PubMed]

118. Bartholomew, A.; Sturgeon, C.; Siatskas, M.; Ferrer, K.; McIntosh, K.; Patil, S.; Hardy, W.; Devine, S.; Ucker, D.; Deans, R.; et al. Mesenchymal stem cells suppress lymphocyte proliferation in vitro and prolong skin graft survival in vivo. Exp. Hematol. 2002, 30, 42-48. [CrossRef]

119. Larocca, R.A.; Moraes-Vieira, P.M.; Bassi, E.J.; Semedo, P.; de Almeida, D.C.; da Silva, M.B.; Thornley, T.; Pacheco-Silva, A.; Câmara, N.O.S. Adipose Tissue-Derived Mesenchymal Stem Cells Increase Skin Allograft Survival and Inhibit Th-17 Immune Response. PLoS ONE 2013, 8, e76396. [CrossRef]

120. Lewis, G.; Heimbach, D.; Gibran, N. Chapter 10-Evaluation of the burn wound: Management decisions. In Total Burn Care; Saunders Elsevier: Philadelphia, PA, USA, 2012; pp. 125-130.

121. Guo, S.; DiPietro, L.A. Factors Affecting Wound Healing. J. Dent. Res. 2010, 89, 219-229. [CrossRef]

122. Moon, K.M.; Park, Y.-H.; Lee, J.S.; Chae, Y.-B.; Kim, M.-M.; Kim, D.-S.; Kim, B.-W.; Nam, S.-W.; Lee, J.-H. The Effect of Secretory Factors of Adipose-Derived Stem Cells on Human Keratinocytes. Int. J. Mol. Sci. 2012, 13, 1239-1257. [CrossRef]

123. Kim, W.-S.; Park, B.-S.; Sung, J.-H.; Yang, J.-M.; Park, S.-B.; Kwak, S.-J.; Park, J.-S. Wound healing effect of adipose-derived stem cells: A critical role of secretory factors on human dermal fibroblasts. J. Dermatol. Sci. 2007, 48, 15-24. [CrossRef]

124. Ono, I.; Yamashita, T.; Hida, T.; Jin, H.-Y.; Ito, Y.; Hamada, H.; Akasaka, Y.; Ishii, T.; Jimbow, K. Combined administration of basic fibroblast growth factor protein and the hepatocyte growth factor gene enhances the regeneration of dermis in acute incisional wounds: Wound Repair and Regeneration. Wound Repair Regen. 2004, 12, 67-79. [CrossRef] [PubMed]

125. Wu, Y.; Chen, L.; Scott, P.G.; Tredget, E.E. Mesenchymal Stem Cells Enhance Wound Healing Through Differentiation and Angiogenesis. Stem Cells 2007, 25, 2648-2659. [CrossRef] [PubMed]

126. Schneider, L.; Cammer, M.; Lehman, J.; Nielsen, S.; Guerra, C.; Veland, I.; Stock, C.; Hoffmann, E.; Yoder, B.; Schwab, A.; et al. Directional Cell Migration and Chemotaxis in Wound Healing Response to PDGF-AA are Coordinated by the Primary Cilium in Fibroblasts. Cell. Physiol. Biochem. 2010, 25, 279-292. [CrossRef] [PubMed]

127. Amini-Nik, S.; Cambridge, E.; Yu, W.; Guo, A.; Whetstone, H.; Nadesan, P.; Poon, R.; Hinz, B.; Alman, B.A. $\beta$-Catenin-regulated myeloid cell adhesion and migration determine wound healing. J. Clin. Investig. 2014, 124, 2599-2610. [CrossRef]

128. Jeschke, M.G.; Patsouris, D.; Stanojcic, M.; Abdullahi, A.; Rehou, S.; Pinto, R.; Chen, P.; Burnett, M.; Amini-Nik, S. Pathophysiologic Response to Burns in the Elderly. EBioMedicine 2015, 2, 1536-1548. [CrossRef]

129. Procházka, V.; Gumulec, J.; Jaluvka, F.; Salounova, D.; Jonszta, T.; Czerny, D.; Krajca, J.; Urbanec, R.; Klement, P.; Martinek, J.; et al. Cell Therapy, a New Standard in Management of Chronic Critical Limb Ischemia and Foot Ulcer. Cell Transplant. 2010, 19, 1413-1424. [CrossRef] 
130. Otero-Vinas, M.; Falanga, V. Mesenchymal stem cells in chronic wounds: The spectrum from basic to advanced therapy. Adv. Wound Care 2016, 5, 149-163. [CrossRef]

131. Lee, M.; Jeong, S.Y.; Ha, J.; Kim, M.; Jin, H.J.; Kwon, S.-J.; Chang, J.W.; Choi, S.J.; Oh, W.; Yang, Y.S.; et al. Low immunogenicity of allogeneic human umbilical cord blood-derived mesenchymal stem cells in vitro and in vivo. Biochem. Biophys. Res. Commun. 2014, 446, 983-989. [CrossRef]

132. Jeschke, M.G.; Rehou, S.; McCann, M.R.; Shahrokhi, S. Allogeneic mesenchymal stem cells for treatment of severe burn injury. Stem Cell Res. Ther. 2019, 10, 337. [CrossRef]

133. Lee, J.; Dibildox, M.; Jimenez, C.; Gallagher, J.; Sayeed, S.; Sheridan, R.; Herndon, D. Chapter 13-Operative wound management. In Total Burn Care; Saunders Elsevier: Philadelphia, PA, USA, 2012; pp. 157-172.

134. McGwin, G.; Cross, J.; Ford, J.; Rue, L. Long-term trends in mortality according to age among adult burn patients. J. Burn Care Rehabil. 2003, 24, 21-25. [CrossRef]

135. Aickara, D.; Candendo, A.; Guzman, W.; Rodriguez-Menocal, L. Use of mesenchymal stem cells to improve healing of second degree burn wound and improve split thickness skin graft outcome. J. Am. Acad. Derm. 2019, 81, AB144.

136. Keck, M.; Lumenta, D.B.; Andel, H.; Kamolz, L.P.; Frey, M. Burn treatment in the elderly. Burns 2009, 35, 1071-1079. [CrossRef] [PubMed]

137. Shahrokhi, S.; Arno, A.; Jeschke, M.G. The use of dermal substitutes in burn surgery: Acute phase: Artificial dermis for acute burn phase. Wound Repair Regen. 2014, 22, 14-22. [CrossRef] [PubMed]

138. Chua, A.W.C.; Khoo, Y.C.; Tan, B.K.; Tan, K.C.; Foo, C.L.; Chong, S.J. Skin tissue engineering advances in severe burns: Review and therapeutic applications. Burns Trauma 2016, 4, 3. [CrossRef] [PubMed]

139. Motamed, S.; Taghiabadi, E.; Molaei, H.; Sodeifi, N.; Hassanpour, S.E.; Shafieyan, S.; Azargashb, E.; Farajzadeh-Vajari, F.; Aghdami, N.; Bajouri, A. Cell-based skin substitutes accelerate regeneration of extensive burn wounds in rats. Am. J. Surg. 2017, 214, 762-769. [CrossRef]

140. Yoshikawa, T.; Mitsuno, H.; Nonaka, I.; Sen, Y.; Kawanishi, K.; Inada, Y.; Takakura, Y.; Okuchi, K.; Nonomura, A. Wound Therapy by Marrow Mesenchymal Cell Transplantation. Plast. Reconstr. Surg. 2008, 121, 860-877. [CrossRef]

141. Sánchez-Muñoz, I.; Granados, R.; Holguín Holgado, P.; García-Vela, J.A.; Casares, C.; Casares, M. The Use of Adipose Mesenchymal Stem Cells and Human Umbilical Vascular Endothelial Cells on a Fibrin Matrix for Endothelialized Skin Substitute. Tissue Eng. Part A 2015, 21, 214-223. [CrossRef]

142. Leonardi, D.; Oberdoerfer, D.; Fernandes, M.C.; Meurer, R.T.; Pereira-Filho, G.A.; Cruz, P.; Vargas, M.; Chem, R.C.; Camassola, M.; Nardi, N.B. Mesenchymal stem cells combined with an artificial dermal substitute improve repair in full-thickness skin wounds. Burns 2012, 38, 1143-1150. [CrossRef]

143. Nakagawa, H.; Akita, S.; Fukui, M.; Fujii, T.; Akino, K. Human mesenchymal stem cells successfully improve skin-substitute wound healing. Br. J. Dermatol. 2005, 153, 29-36. [CrossRef] 